\title{
Physicians' Brain Drain: Investigating the Determinants to Emigrate Through Empirical Evidence
}

\author{
Evgenia Anastasiou ${ }^{1}$, Georgia Anagnostou², George Theodossiou ${ }^{3}$, Vasileios Papamargaritis ${ }^{4}$ \\ Postdoctoral Researcher, Laboratory of Demographic and Social Analyses, Department of Planning and Regional Development, University of Thessaly, Greece \\ ¿Economist, MBA, Department of Business Administration, University of Thessaly, Larissa, Greece \\ Professor, Department of Business Administration, University of Thessaly, Larissa, Greece \\ 'Department of Business Administration, University of Thessaly, Larissa, Greece
}

\begin{tabular}{l}
\hline ARTICLE INFO \\
\hline Article History \\
Received 14 May 2020 \\
Accepted 26 June 2020 \\
\hline JEL Classifications \\
J1, J2 1, J24, J6, O15
\end{tabular}

ABSTRACT
Purpose:
The economic crisis in Greece has caused widespread suffering both in society and the
economy. Among other things, new forms of geographical mobilities emerged highlighting
the country's inability to retain a scientifically skilled workforce. One of the most important
scientific branches been hit is the medical one. The purpose of this study is to identify the
intention as well as the main factors that push young greek physicians to emigrate. intention as well as the main factors

For the present study, a tool for assessing young physicians' perceptions was designed and field research was performed on 239 medical school students and young physicians for up to 39 years. Descriptive and inferential statistical analysis was used to describe the data and generalize the results. Finally, Factor Analysis (Principal Component Analysis) was used to condense the initial variables and capture the determinants in physicians' brain drain.

Findings:

Young physicians show high intention to seek employment abroad. There are differences between men and women regarding their perceptions of the possible causes of emigration. Women consider more than men that unemployment, employment prospects, and opportunities and quality of life to be the most important reasons in the migratory decision. In addition, the young doctors whose family incomes are either very low or quite high are more receptive to looking for work abroad. Finally, the multivariate analysis highlights four main determinants feeding physicians decision-making; homeland's social identity, lack of prospects, unfavorable economic environment, and continuation of studies.

Research limitations/implications:

Keywords:

Brain Drain, Physicians, Migration, Human Geography, Principal Component Analysis, Greece
The period of the field research was conducted from September to November 2018. As a result, there are restrictions on whether participants' responses are affected by the economic crisis or not, as Greece in 2018 began to show macroeconomic stability.

Originality/value:

In the last decade, a large wave of young scientists' emigration has been recorded in Greece. This wave intensified in 2012 and became permanent in the following years, taking on large-scale exodus, with high annual outflows. Brain Drain as an evolving phenomenon has been studied both by the national and international academic community. However, in the case of Greece, the research of perceptions, intentions, and the main reasons for brain drain by medical professionals is limited. The present study seeks to fill the gap found in the literature through field research about the determinants of physicians' brain drain in Greece.

\section{Introduction}

Greece is a country with a strong migration history in terms of both internal (Anastasiou \& Duquenne, 2017) and external migration (Loizou et al., 2014). The two major waves of external migration that took place in the early and mid-20th centuries were mainly involving unskilled workforce. The changing face of immigration, however, continues to fuel Greece's historic tradition, abandoning the country in search of opportunities but also better working and living conditions. 
The Greek economy and society are once again experiencing a modern phase of mass migration in its history. The economic crisis of 2008 in the context of horizontal economic, political and social changes, fed back a new wave of external migration with a direct impact on the highly specialized young workforce (Cavounidis, 2015). Among the affected scientific disciplines is the physician, who suffers significant losses.

The investigation of the intention of the Greek medical personnel to move professionally abroad as well as the factors of its impetus in other countries is very limited and a gap is identified in the field of bibliography. Taking into consideration the extensive nature of the phenomenon, the investigation of both the perceptions and intentions of Greek physicians is a matter of increased interest.

The paper is divided into four sections: In the first section, a short literature review on both brain drain in Greece and physicians' brain drain is taking place as well the driving forces of physicians' brain drain are explored. In the subsequent section (Data and Methodology) information is provided for the field research and the methodological approach is analyzed. Finally, in the Results section, there are presented the main descriptive findings from the analysis conducted and the principal components affecting young physicians emigrating decisions. The Conclusions and Recommendations discuss the results conducted from the quantitative analysis.

\section{Review of Literature}

\subsection{The Greek Brain Drain}

In the migratory history of the Greeks, the mass exits came after a recession that widened the country's prosperity gap in comparison with the most developed countries. It is worth mentioning that before the economic crisis the Greeks were among the European people with the greatest stiffness in emigration (Vandenbrande et al., 2006), while just one year before the crisis the percentage of Greeks who would choose to work in another country, in case of unemployment in Greece, was very low compared to the average of the EU (Special Eurobarometer 337, 2010). The change in economic and social conditions in Greece over the last decade has highlighted external migration on the one hand as a survival strategy for some, and on the other hand as an attractive option for developing a career of another part of Greeks (Labrianidis \& Pratsinakis, 2016). Nevertheless, an issue emerges on the social integration of the Greek migrants at the new workplace Mitsakis \& Mendonca, 2017). Brain drain as a phenomenon triggered by the economic crisis is particularly evident in European Southern countries (especially Italy, Spain, Portugal), as their economies have been hit hard (Christopoulos et al., 2014; Marinakou et al., 2016). The most popular migratory destinations are European countries with an emphasis on Germany and the United Kingdom, followed by the United States and Australia (Christopoulos et al., 2014; Labrianidis \& Pratsinakis, 2016), while mobilities were also observed in the large urban areas of Canada, especially after 2012 (Aravossitas \& Sugiman, 2019). As regards the last, a big part concerns Greek people with Canadian citizenship (Aravossitas \& Sugiman, 2019).

In the era of crisis, the greatest exportable product of Greece is its scientific staff (Marinakou et al., 2016), recording a loss of 12 billion euros per year (Endeavor Greece, 2014). The estimated loss of human capital between 2008 and 2013 ranges from 350000 (Endeavor estimation) to 427000 (Bank of Greece estimation) young scientists. It is worth mentioning that, based on recent research, young people who want to immigrate often have highly structured and comprehensive reasoning about their intentions, in contrast with the reluctant ones who make vague arguments about the reasons that led them to reject it (Theodossiou et al., 2017).

Among the most important reasons for relocation are not only unemployment and the unfavorable economic situation, but also the inability of the state to provide opportunities for excellence and personal development (Bank of Greece, 2016; Duquenne \& Metaxas, 2017). "Generation E" (expats) or "generation G" (young, talented and Greek) or "generation We" is the generation of Greek scientists (Bank of Greece, 2016) who, in the last decade, immigrated to developed economies looking for opportunities for social and economic progress (Damanakis, 2014; Endeavor Greece, 2014; ICAP, 2015; Labrianidis \& Pratsinakis, 2016; Labrianidis \& Vogiatzis, 2013).

The profile of emigrants under this type of mobility involves young Greeks about 30 years old, with high academic education, changing their country of residence for several economic reasons. Of the 190000 Greek graduates living abroad, 140000 left the country after 2010. In particular, $75 \%$ are graduates of higher education and one-third of them are either postgraduate students or graduates of medical schools and the Polytechnic (Labrianidis \& Pratsinakis, 2016).

The push factors of Greek scientists abroad stem from both a general sense of lack of prospects in their homeland (Labrianidis \& Vogiatzis, 2013) and an accumulated frustration for the gloomy socio-economic situation in Greece, accompanied by deep frustration as regards the political status and state institutions (Duquenne \& Metaxas, 2017). In addition, corruption, fraud, "partnership", unworthiness, protection, nepotism, and customer bonds (Panagiotakopoulos, 2020; Duquenne \& Metaxas, 2017; Anastasiadou, 2016; Giousmpasoglou et al., 2016; ICAP, 2015; Tsekeris et al., 2015) are significant obstacles to the development of the career of the new skilled workforce. Besides, classical reasons for leaving the country remain the low wages and limited career opportunities (Mitsakis \& Mendonca, 2017).

Moreover, data on students studying social sciences reveal the deterioration of employment opportunities in Greece (Kalamatianou \& Kougioumoutzaki, 2012). Even though lack of work is one of the most important factors leading to emigration decisions, it does not seem to be entirely determinant. Many of the high-skilled immigrants do not mainly leave to search for work due to high unemployment in Greece, but mostly to seek better working conditions, prospects and job stability, benefits that are degraded at the moment in Greece. The majority of migrants in this third mass exodus are very dissatisfied with the employment conditions, career prospects, and the relevance of their job to their educational background. The above concerns of young people with high qualifications, under 
conditions of pressure and strict austerity, can lead to a mass exodus abroad (Theodoropoulos et al., 2014), with Greece incurring particularly negative consequences. Among other negative things, we also observe a reduction in the capacity of the economy, a downgrading of research activities at the domestic level, and a shrinking of the country's human resources.

Repatriation in the near future is neither a plan nor a wish, taking into consideration the existing situation (Labrianidis \& Pratsinakis, 2016; Markantonatou, 2013). Till now, the large escape of young scientists abroad is perhaps an exaggerated scenario, as the estimates of the number of young people leaving the country do not seem to compose a mass phenomenon. At this point, it is worth mentioning that in addition to Greek scientists there is a large group of second-generation immigrants in Greece who choose to remain in Greece and aspire to their personal and professional development (Michail \& Christou, 2018).

\subsection{Greek Physicians’ Brain Drain}

Greece is one more example of a country that was hit by the financial crisis and has exiled a significant portion of the medical field. The ratio of doctors to the country's population may remain the highest in the EU, specifically 6.6 doctors correspond per 1000 inhabitants, in comparison to 3.6 which is the mean of the European Union (OECD, 2019). However, since 2010 there has been a steady decline in the number of physicians (Figure 1) mainly attributed to the brain drain phenomenon. Since 2015, however, there has been a dramatic increase in the number of doctors in Greece $(+3.3 \%)$, which may hide a possible brain gain, given that the number of students admitted and graduated from medical schools in the country remains in relatively stable levels.

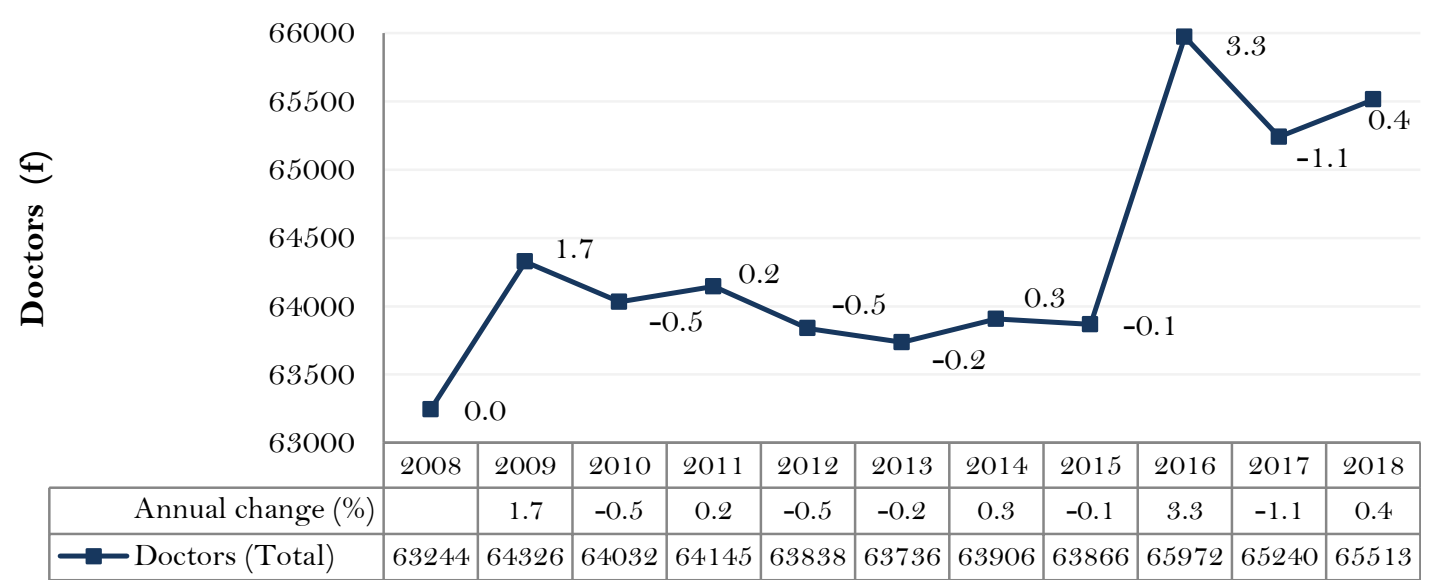

Figure 1: Doctors in Greece, 2008-2018

More than 18000 Greek physicians work abroad and many of them have left the country due to the economic crisis (Athens Medical Association, 2019a). In particular, in the last decade, more than 10000 doctors originating from Athens have left the country. At the same time, unemployment or underemployment affects $25 \%$ of the members of the Athens Medical Association (AMA) (Athens Medical Association, 2019b), while in 2018 the unemployment of doctors in Greece reached record levels, as 28\% (2100 people) of the members of the Medical Association of Athens were unemployed or underemployed. Between 2013 and 2018,1500 doctors a year applied for certificates in order to move abroad. In 2018, the registered AMA members showed a decrease of $4 \%$ compared to 2009 and $1.1 \%$ compared to 2017 (Athens Medical Association, 2018).

Young physicians without a medical specialty are on standby situations and show a declining trend throughout the study period (Figure 2), except for 2016 when there was a slight increase. Specialized doctors show slightly lower trends, of lower intensity in comparison with the ones expecting medical specialty. Combining the simultaneous economic crisis and the brain drain of all scientific disciplines in the country, it appears that the decline in the number of doctors who are waiting for a specialty or are being trained may be due to the leak abroad. The percentage of specialized medical personnel leaving abroad has been increased in a fivefold rate during the five years $2007-2012$ (Athens Medical Association, 2013). In 2019, AMA issued 1097 certificates to doctors who planned to go abroad, whereas 348 were for doctors without specialization and 749 for specialized (Athens Medical Association, 2019a). 


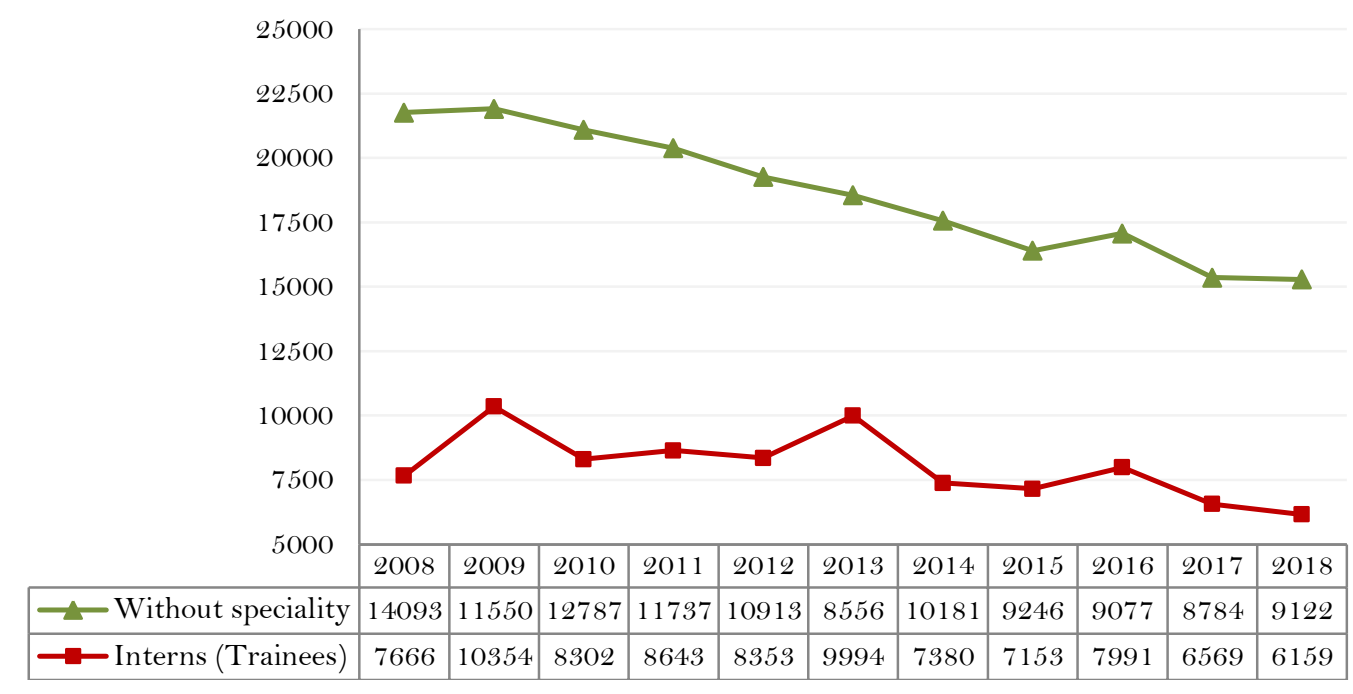

Figure 2: Interns and Doctors without a specialty in Greece, 2008-2018

The effort of our society to retain the medical workforce in the country is extremely significant as the total expenditure per capita until the end of studies exceeds the amount of 85000 euros (Athens Medical Association, 2019a). Consequently, the phenomenon of brain drain, in addition to the migratory component, has direct economic implications due to the loss of resources invested in medical training (Sidiropoulos et al., 2017).

Research on the leakage of push factors of Greek physicians is very limited. Among the most important factors are limited opportunities, insecurity, declining income, high taxation, and limited funding for biomedical research (Ifanti et al., 2014). A similar study by medical graduates showed that the vast majority are willing to leave Greece in search of work abroad, with dominant destinations in Germany and the United Kingdom (Labiris et al., 2014). At the same time, it turned out that young doctors are negatively affected by unworthiness in combination with their low absorption by the private and public sectors (Sidiropoulos et al., 2017). An important element is also the choice of the specialty that can financially support the desired lifestyle of future doctors (Labiris et al., 2014).

Greece is currently deprived of a dynamic new generation of doctors who could contribute through their up-todate knowledge to the rejuvenation of aging health care (Filippidis, 2016). The literature suggests a number of measures to encounter physicians' brain drain. It is recommended that motivational theories (Maslow, Adams, Herzberg, McClelland) could be applied to medical personnel in order to observe human behavior, attitudes, and perceptions (Chatziprodromidou et al., 2018). Interventions should aim to improve working conditions, postgraduate education, biomedical research, and health tourism (Sidiropoulos et al., 2017).

\section{Data and Methodology}

In order to explore the main factors affecting the intention of greek physicians to emigrate field research was conducted using questionnaires. The study population concerns the medical students of the seven medical schools in Greece so as the young physicians up to the age of 39 years old operating in Greece. The research process lasted from September to November 2018 and the participants were selected through random sampling techniques. The survey was internet-based, so the questionnaires were delivered online through the institutional emails provided by Greek medical schools and medical associations.

The research tool designed for the purpose of the present methodology consists of 21 questions (Table 1) exploring the participants' perceptions of emigrating. The data were measured with 5-point Likert scales in order to provide reliable estimates (Nemoto \& Beglar, 2014). Finally, 239 young physicians participated in the research (sample size), while the confidence intervals deal with the sampling. 
Table 1: Factors affecting physicians brain drain

\begin{tabular}{|c|c|c|}
\hline Push Factors & Variables & Relevant Literature \\
\hline $\begin{array}{l}\text { Professional and Economic } \\
\text { reasons }\end{array}$ & $\begin{array}{l}\text { Unemployment } \\
\text { Lack of employment } \\
\text { opportunities } \\
\text { Lack of perspectives } \\
\text { Career promotion } \\
\text { Low wages } \\
\text { High taxation } \\
\text { High living costs } \\
\text { Low specialization }\end{array}$ & $\begin{array}{l}\text { (Gouda et al., 2015; Hagander et } \\
\text { al., 2013; Ifanti et al., 2014; Klein } \\
\text { et al., 2009; Marchal \& Kegels, } \\
\text { 2003; Ricketts, 2010; Sidiropoulos } \\
\text { et al., 2017; Syed et al., 2007) }\end{array}$ \\
\hline Personal reasons & $\begin{array}{l}\text { Poor quality of life } \\
\text { Experiences } \\
\text { Unfavorable conditions to } \\
\text { establish a family } \\
\text { General disappointment } \\
\text { Seek better luck }\end{array}$ & $\begin{array}{l}\text { (Akl et al., 2007; Arah et al., 2008; } \\
\text { Benamer et al., 2009; Gouda et al., } \\
\text { 2015; Klein et al., 2009; Labiris et } \\
\text { al., 2014; Sheikh et al., 2012) }\end{array}$ \\
\hline Social reasons & $\begin{array}{l}\text { Social exclusion } \\
\text { Marginalization } \\
\text { Racism } \\
\text { Criminality } \\
\end{array}$ & $\begin{array}{l}\text { (Akl et al., 2007; Arah et al., 2008; } \\
\text { Sheikh et al., 2012) }\end{array}$ \\
\hline Educational reasons & $\begin{array}{l}\text { Master studies } \\
\text { Ph.D. studies } \\
\text { Erasmus studies } \\
2^{\text {nd }} \text { degree studies }\end{array}$ & $\begin{array}{l}\text { (Akl et al., 2007; Benamer et al., } \\
\text { 2009; Hagander et al., 2013; Ifanti } \\
\text { et al., 2014; Sidiropoulos et al., } \\
\text { 2017; Syed et al., 2007) }\end{array}$ \\
\hline
\end{tabular}

Source: Authors' compilation

As concerns the data analysis methods, descriptive statistical analysis was performed to describe the sample profile, while statistical hypothesis testing examined the influence of gender and income on brain drain push factors. A subsequent multivariate analysis was undertaken. Initially, exploratory factor analysis was used to identify and validate the structure of the questions and reduce their count. To ensure the satisfactory endogenous correlations, the Kaiser-Mayer-Olkin (KMO) statistical test and the Bartlett Sphericity Test (B.S.) were used. Factor extraction was done by Principal Components Analysis and the axes of the factors were rotated by Varimax rotation. The total sampling rate $(\mathrm{KMO})$ is 0.822 , so it is considered appropriate to use the factor analysis tool as the data show remarkable homogeneity. The Principal Component Analysis presents four Principal Components, that reduce significantly the dimensions of the medical brain drain in Greece ( $81 \%$ of dimension reduction), and in parallel interpret $70 \%$ of the total variance.

\section{Results}

The sample consists of 239 participants (Table 2). The majority of them are women (56.8\%). The largest percentage concerns students before obtaining their basic degree (45.9\%), following from doctors in a medical specialty (29\%). Annual household income is more evenly distributed among sample participants. It is observed an association between gender and age $(\mathrm{p}<.05)$ and gender and annual household income $(\mathrm{p}<0.05)$, whereas Academic/professional status, is completely independent of gender $(\mathrm{p}>.05)$. 
Table 2: Profile of the sample

\begin{tabular}{|c|c|c|c|c|c|c|c|}
\hline \multirow{2}{*}{ Sample } & Men & $\%$ & Women & $\%$ & Total & $\%$ & \multirow{2}{*}{$\begin{array}{l}\text { p-value } \\
\text { Chi- } \\
\text { square }\end{array}$} \\
\hline & 112 & 43.2 & 147 & 56.8 & 259 & 100 & \\
\hline \multicolumn{8}{|l|}{ Age } \\
\hline $18-24$ & 54 & 48.2 & 94 & 63.9 & 148 & 57.1 & \multirow{2}{*}{.011} \\
\hline 25-39 & 58 & 51.8 & 53 & 36.1 & 111 & 42.9 & \\
\hline \multicolumn{8}{|c|}{ Academic/professional status } \\
\hline BSc student & 45 & 40.2 & 74 & 50.3 & 119 & 45.9 & \multirow{4}{*}{.369} \\
\hline $\mathrm{MSc} / \mathrm{PhD}$ student & 19 & 17.0 & 17 & 11.6 & 36 & 13.9 & \\
\hline in Medical speciality & 35 & 31.3 & 40 & 27.2 & 75 & 29.0 & \\
\hline Rural service doctor & 13 & 11.6 & 16 & 10.9 & 29 & 11.2 & \\
\hline \multicolumn{8}{|c|}{ Annual household income } \\
\hline$<10000 €$ & 20 & 17.9 & 40 & 27.2 & 60 & 23.2 & \multirow{4}{*}{.036} \\
\hline $10000-15000 €$ & 19 & 17 & 35 & 23.8 & 54 & 20.8 & \\
\hline $10000-25000 €$ & 31 & 27.7 & 37 & 25.2 & 68 & 26.3 & \\
\hline$>25000 €$ & 42 & 37.5 & 35 & 23.8 & 77 & 29.7 & \\
\hline
\end{tabular}

As seen in Table 3, job search intention abroad is high $(\mathrm{p}<.05)$. Among the strongest reasons that contribute to the decision of young doctors for future migration $(\mathrm{p}<.05)$ are the lack of prospects, career advancement, low wages, gaining experience, general frustration, and searching for better luck. In contrast, participants are less likely to immigrate due to the conditions of social exclusion, high marginalization, criminality or to obtain a second degree (p $<.05)$. The high cost of living is equally a low-intensity factor.

Table 3: Descriptive statistics of push factors

\begin{tabular}{|c|c|c|}
\hline Push Factors & Mean & $\begin{array}{l}\text { Sig. } \\
\text { (2-tailed) }\end{array}$ \\
\hline Job search intention abroad & $5.21(1.8)$ & .000 \\
\hline Unemployment & $4.76(2.1)$ & .000 \\
\hline Lack of perspectives & $5.54(1.6)$ & .000 \\
\hline Career promotion & $5.16(1.7)$ & .000 \\
\hline Low wages & $5.25(1.7)$ & .000 \\
\hline High taxation & $4.35(1.8)$ & .003 \\
\hline High living costs & $3.46(1.7)$ & .000 \\
\hline Lack of employment opportunities & $4.76(1.8)$ & .000 \\
\hline Low specialization & $4.87(1.8)$ & .000 \\
\hline Poor quality of life & $4.24(2.0)$ & .067 \\
\hline Experiences & $5.36(1.7)$ & .000 \\
\hline $\begin{array}{l}\text { Unfavorable conditions to establish a } \\
\text { family }\end{array}$ & $3.98(1.9)$ & .852 \\
\hline General disappointment & $5.30(1.8)$ & .000 \\
\hline Seek better luck & $5.22(1.8)$ & .000 \\
\hline Master studies & $3.90(2.2)$ & .456 \\
\hline PhD studies & $4.33(2.1)$ & .015 \\
\hline Erasmus studies & $3.27(2.3)$ & .000 \\
\hline 2nd degree studies & $2.39(1.8)$ & .000 \\
\hline Social exclusion & $2.64(1.8)$ & .000 \\
\hline Marginalization & $2.62(1.8)$ & .000 \\
\hline Racism & $2.75(1.9)$ & .000 \\
\hline Criminality & $2.95(2.0)$ & .000 \\
\hline
\end{tabular}


There is a difference in means between men and women $(\mathrm{p}<.05)$ as concerns their perceptions about unemployment (men: $\mathrm{M}=4.17, \mathrm{SD}=2.2$; women: $\mathrm{M}=5.20, \mathrm{SD}=1.9$ ), lack of perspectives (men: $\mathrm{M}=5.22, \mathrm{SD}=1.8$; women: $\mathrm{M}=5.78, \mathrm{SD}=1.5$ ), living costs (men: $\mathrm{M}=3.13, \mathrm{SD}=1.6$; women: $3.71, \mathrm{SD}=1.8$ ), employment opportunities (men: $\mathrm{M}=4.29, \mathrm{SD}=2.0$; women: $5.12, \mathrm{SD}=1.7$ ), quality of life (men: $\mathrm{M}=3.93, \mathrm{SD}=2,1$; women: $4.47, \mathrm{SD}=1.9$ ), and further studies (men: $\mathrm{M}=3.50 \mathrm{SD}=2.2$; women: $4.20, \mathrm{SD}=2.1$ ) as motives for leaving the country.

In addition, there is a statistically significant difference for doctors whose income ranges between 10000-25000 $(\mathrm{M}=4.73, \mathrm{SD}=2.1 ;)$ and those with less than $10000(\mathrm{M}=5.68, \mathrm{SD}=1.5)$ or greater than $25000(\mathrm{M}=5.58, \mathrm{SD}=1.5 ;)$ in their intention to look for work abroad, with the second to have much stronger intention $(\mathrm{p}<.05)$. The lack of prospects is an incentive for doctors of all incomes to abandon Greece but it seems to have greater intensity in low incomes $(\mathrm{p}<.05)$. The same perception is found in the unemployment factor where participants with an income of more than 10000 are slightly positively willing to leave their country as a result of unemployment. In contrast, young scientists with incomes below 10000 have a strong intention to move abroad because of this $(\mathrm{p}<.05)$. Among the positive factors that repel the country's medical personnel is the promotion of their career and it significantly influences all incomes. Particularly significant is the finding that respondents with positive intention for job search abroad $(81 \%)$ could return to Greece if conditions got better.

\subsection{Factors affecting physicians' job search intention abroad}

The four main components that have been detected (Table 4), reveal that the push factors for Greek physicians' brain drain arise from a general feeling of the lack of prospects in their homeland, an accumulated disappointment about the socio-economic situation in Greece, accompanied by the deep disappointment by homeland's social identity. In addition, stagnant conditions are major impediments to the career development of Greek medical care personnel. And finally, the continuation of studies remains a classical reason for leaving the country.

Table 4: Component Matrix

\begin{tabular}{|c|c|c|c|c|c|}
\hline \multirow[b]{2}{*}{ Items } & \multirow[b]{2}{*}{$\mathrm{H}^{2}$} & \multicolumn{4}{|c|}{ Principal Components } \\
\hline & & $\begin{array}{l}\text { Homeland's } \\
\text { social } \\
\text { identity }\end{array}$ & $\begin{array}{l}\text { Lack of } \\
\text { prospects }\end{array}$ & $\begin{array}{l}\text { Unfavorable } \\
\text { economic } \\
\text { environment }\end{array}$ & $\begin{array}{l}\text { Continuation } \\
\text { of Studies }\end{array}$ \\
\hline Marginalization & .733 & .913 & & & \\
\hline Social Exclusion & .484 & .898 & & & \\
\hline Racism & .691 & .879 & & & \\
\hline Criminality & .759 & .801 & & & \\
\hline Poor quality of life & .751 & .518 & & & \\
\hline Seek better luck & .763 & & .848 & & \\
\hline $\begin{array}{l}\text { General } \\
\text { disappointment }\end{array}$ & .766 & & .840 & & \\
\hline Experiences & .867 & & .719 & & \\
\hline Unemployment & .795 & & & .804 & \\
\hline $\begin{array}{l}\text { Lack of employment } \\
\text { opportunities }\end{array}$ & .665 & & & .795 & \\
\hline Low wages & .768 & & & .575 & \\
\hline High taxation & .589 & & & .538 & \\
\hline Postgraduate Studies & .545 & & & & .846 \\
\hline Doctorate & .563 & & & & .831 \\
\hline Obtain 2nd degree & .509 & & & & .590 \\
\hline$\%$ of Total Variance & & $35.4 \%$ & $15.9 \%$ & $10.5 \%$ & $7.4 \%$ \\
\hline
\end{tabular}

1 st component: Homeland's social identity (35.4\% of total variance).

The first complex component, which contributes to the highest percentage in the interpretation of physicians' brain drain intention, highlights the social aspect of the phenomenon. It is composed of five individual variables with very high factor loadings and at the same time, they are positively correlated. The combination of the initial variables reflects the climate that results from marginalization, social exclusion, racism, crime, and low living standards. The above compose an abnormal social environment with conditions incompatible with the lower acceptable threshold of quality of life of young doctors.

2nd component: Lack of prospects (15.9\%).

The second principal component participates with a particularly significant percentage in the interpretation of the under study phenomenon and reflects the lack of development and career prospects in the country. It consists of three initial variables, two of which have very high factor loadings, which are positively correlated with each other. The logic of 
interpretation is based on the general frustration of young scientists. It springs from the unattractive inner environment where it functions as a pole of repulsion for young scientists to seek new nodes of fortune and experiences.

\section{3rd component: Unfavorable economic environment (10.5\%).}

The third principal component is both economic and social and defines the economically stationary conditions of Greece. It consists of four initial variables that are positively correlated. The hyper-variable is formed by unemployment, which may indirectly reflect the changing conditions in the medical industry, lack of professional opportunities, low wages, and high taxation. Therefore, the unfavorable economic environment feeds the outflow of new doctors abroad.

4th component: Continuation of Studies (7.4\%).

The latter component has the least weight in the interpretation of physicians' brain drain; however, it is a classic reason why young scientists are leaving the country. Continuing studies, whether it is a doctoral degree or a master's degree or even obtaining a second degree, is a timeless factor in interpreting the phenomenon. This component also reflects the need and the willingness for young physicians to engage in research that is often limited and underpaid in Greece. It consists of three initial variables with positive correlations and high factor loadings in the first two.

The analysis conducted on 239 young physicians highlights high intentions to seek employment abroad. There are statistically significant differences between men and women regarding their perceptions of the possible causes of emigration. Women consider more than men that unemployment, employment prospects, and opportunities and quality of life to be the most important reasons in the migratory decision. An important aspect of migratory decision making plays also the family income. The young doctors whose family income is either very low or quite high are more receptive to looking for work abroad. Finally, the multivariate analysis highlights four main determinants feeding physicians decision-making; homeland's social identity, lack of prospects, unfavorable economic environment, and continuation of studies.

\section{Conclusion and Recommendations}

In Greece, in recent years, there has been a shrinking trajectory of the medical workforce, as the brain drain has penetrated this scientific field as well. Since 2010 , there has been a steady decline in the number of physicians, which is largely attributed to brain drain. The domestic health system and the chronic pathogens it faces do not have a lot of leeway for the suspension/limitation of the phenomenon, as for the time being the incentives for them to return to the country are not attractive, confirming that the Greek State had not developed a risk culture (Eleftheriadis \& Vyttas, 2016).

The emigration of highly qualified scientific personnel has multiple effects on Greek society. Firstly, it weakens the country scientifically. As a result, there is a threatening shortage of doctors, leading to a major undermining of the quality of health services and making it difficult to develop medical innovation in Greece. Physicians' brain drain has parallel unfavorable economic implications as Greece does not avail of the scientists though funded them for their studies.

A barometer in the decision for young physicians to emigrate is the social identity of Greece, characterized by racism, social exclusion, criminality, and marginalization, which is inconsistent with the ideal level of the desired quality of life of doctors. The lack of development prospects is also an important impulse in the emigration decision. Finally, the factors that strengthen their intention to look for work abroad are the domestic unfavorable economic environment as well as the possibilities for conducting research and postgraduate specialization that exist abroad. The results of the analysis confirm previous research on Greek students as regards the social injustice and non-confidence to the politicians and their intention to restrain the economic situation in the country, mainly due to nepotism and corruption (Panagiotakopoulos, 2020; Anastasiadou, 2016; Giousmpasoglou et al., 2016).

In a country like Greece, where the geographical distribution of doctors has inequalities, it is imperative for the State to intercept this phenomenon. An optimistic compensatory factor in the intention of emigration of young doctors abroad is their intention to repatriate in case of improvement of the socio-economic conditions. This finding suggests the need to create a health map, record needs, and link the entrants of medical schools with these needs, taking into account the geographical peculiarities of the country. Furthermore, this has to be brought to the attention of the Greek policy makers and political actors to create bridges that will provide opportunities in the medical staff so that it remains in the country.

The present research could be further developed by focusing on the actions needed to intercept physicians' emigration. This direction would possibly benefit the functioning of the health system, and reverse the brain drain into brain gain.

\section{Acknowledgment}

i. The present research was financed by the authors.

ii. Senior authorship is shared. 
Akl, E. A., Maroun, N., Major, S., Afif, C., Chahoud, B., Choucair, J., Sakr, M., \& Schünemann, H. J., 2007. Why are you draining your brain? Factors underlying decisions of graduating Lebanese medical students to migrate. Social Science and Medicine, 64(6), 1278-1284. https://doi.org/10.1016/j.socscimed.2006.10.021

Anastasiadou, S., 2016, Economic Crisis in Greece and the Consequential "Brain Drain." In The First Decade of Living with the Global Crisis (pp. 113-120). Springer, Cham. https://doi.org/10.1007/978-3-319-24267-5_9

Anastasiou, E., \& Duquenne, M-N, 2017, The return to the rural in Greece during the last decade: A methodological approach of the potential spatial patterns. In V. Janeska \& A. Lozanoska (Eds.), Fifth International Conference of the Balkans demography: The population of the Balkans at the dawn of the 21st century (pp. 331-354). Institute of Economics - Skopje, Ss. Cyril and Methodius University in Skopje, Republic of Macedonia.

Arah, O. A., Ogbu, U. C., \& Okeke, C. E., 2008, Too Poor to Leave, Too Rich to Stay: Developmental and Global Health Correlates of Physician Migration to the United States, Canada, Australia, and the United Kingdom. American Journal of Public Health, 98(1). https://doi.org/10.2105/AJPH.2006.095844

Aravossitas, T., \& Sugiman, M., 2019, From Brain Drain to Brain Gain: New Greek Migration to Canada and Implications for the Community. In New Migration of Families from Greece to Europe and Canada (pp. 33-56). Springer VS, Wiesbaden. https://doi.org/10.1007/978-3-658-25521-3_3

Athens Medical Association, 2013, Press Release. The trend of medical immigration.

Athens Medical Association, 2018, Press Release. Impoverishment of the medical staff

Athens Medical Association, 2019a, Press Release. Information on Greek doctors.

Athens Medical Association, 2019b, Press Release. 1,100 Doctors Left Greece in 2019.

Bank of Greece, 2016, Economic Bulletin, Issue 43.

Benamer, H. T. S., Bredan, A., \& Bakoush, O., 2009, The Libyan doctors' brain drain: An exploratory study. BMC Research Notes, 2(1), 242. https://doi.org/10.1186/1756-0500-2-242

Cavounidis, J., 2015, The changing face of emigration: Harnessing the potential of the new Greek diaspora.

Chatziprodromidou, I. P., Emmanouilides, C., Yfanti, F., Ganas, A., Roupas, T., Varsamidis, K., \& Apostolou, T. M., 2018, Brain drain: The Greek phenomenon. International Research Journal of Public and Environmental Health, 4(1 1), 1-5.

Christopoulos, A. G., Kalantonis, P., Stavroulakis, D., \& Katsikides, S., 2014, The Migration of Greek Scientists Abroad and the Phenomenon of Brain-Drain in the Current Crisis. International Journal of Business, Humanity and Technology, 4(2), 106-114.

Damanakis, M., 2014, Greek New emigration to Germany. In M. Damanakis, S. Konstantinidis, \& A. Tamis (Eds.), New Migration to and from Greece (pp. 139-177). The University of Crete.

Duquenne, M.-N., \& Metaxas, T., 2017, La Fuite Des Cerveaux: Motivations Des Jeunes Grecs A S'expatrier. 54ème Colloque ASRDLF - 15th Conference ERSA-GR, Cities and Regions in a Changing Europe: Challenges and Prospects.

Endeavor Greece, 2014, Creating Jobs For Youth. https://www.snf.org/media/3527145/Endeavor-Study.PDF

Eleftheriadis, I., \& Vyttas, V., 2016, Creating a culture of risk in the Greek public administration. A brief retrospect on the memorandum era. International Journal of Business and Economic Sciences Applied Research, 9(2), 65-71.

Filippidis, F., 2016, Emigrating young physicians leave Greece with an aging health workforce. Journal of Public Health, $38(4), 587$. https://doi.org/https://doi.org/10.1093/pubmed/fdv 193

Giousmpasoglou, C., Marinakou, E., \& Paliktzoglou, V. P., 2016, The Brain Drain Phenomenon in Higher Education in Greece: Attitudes and Opinions on the Decision to Immigrate. 3rd Annual International Conference on Humanities \& Arts in a Global World.

Gouda, P., Kitt, K., Evans, D. S., Goggin, D., McGrath, D., Last, J., Hennessy, M., Arnett, R., O’Flynn, S., Dunne, F., \& O'Donovan, D., 2015, Ireland's medical brain drain: Migration intentions of Irish medical students. Human Resources for Health, 13(1), 11. https://doi.org/10.1186/s12960-015-0003-9

Hagander, L. E., Hughes, C. D., Nash, K., Ganjawalla, K., Linden, A., Martins, Y., Casey, K. M., \& Meara, J. G., 2013, Surgeon migration between developing countries and the United States: Train, retain, and gain from brain drain. World Journal of Surgery, 37(1), 14-23. https://doi.org/10.1007/s00268-012-1795-6

Hellenic Statistical Authority. (2019). Follow up on the number of physicians and dentists, 2018.

ICAP, 2015, Results of research on the phenomenon of "Brain drain" - Press Release. https://www.icap.gr/default.aspx? $t=$ ECNewsLetter.aspx\&id=9746\&nt=150\&lang=1

Ifanti, A. A., Argyriou, A. A., Kalofonou, F. H., \& Kalofonos, H. P., 2014, Physicians' brain drain in Greece: A perspective on the reasons why and how to address it. Health Policy, 117(2), 210-215. https://doi.org/10.1016/j.healthpol.2014.03.014

Kalamatianou, A., \& Kougioumoutzaki, F., 2012, Employment Status and Job-Studies Relevance of Social Science Graduates: The Experience from a Greek Public University. International Journal of Economic Sciences and Applied Research, 5(1), 51-75.

Klein, D., Hofmeister, M., Lockyer, J., Crutcher, R., \& Fidler, H., 2009, Push, Pull, and Plant: The Personal Side of Physician Immigration to Alberta, Canada. International Family Medicine, 41(3), 197-201.

Labiris, G., Vamvakerou, V., Tsolakaki, O., Giarmoukakis, A., Sideroudi, H., \& Kozobolis, V., 2014, Perceptions of Greek medical students regarding medical profession and the specialty selection process during the economic crisis years. Health Policy, 117(2), 203-209. https://doi.org/10.1016/j.healthpol.2014.04.009

Labrianidis, L., 2014, Investing in leaving: The Greek case of international migration of professionals. Mobilities, 9(2), 314-335.

Labrianidis, L., \& Pratsinakis, M. (2016). Greece's new Emigration at times of Crisis (GreeSE Paper No.99).

Labrianidis, L, \& Vogiatzis, N., 2013, Highly Skilled Migration: What Differentiates the 'Brains' Who Are Drained from Those Who Return in the Case of Greece? Population, Space and Place, 19(5), 472-486. https://doi.org/10.1002/psp. 1726

Loizou, E., Michailidis, A., \& Karasavvoglou, A., 2014, Return migration: Evidence from a reception country with a short migration history. European Urban and Regional Studies, 2 1(2), 161-174. https://doi.org/10.1177/0969776412444507

Marchal, B., \& Kegels, G., 2003, Health workforce imbalances in times of globalization: brain drain or professional mobility? The International Journal of Health Planning and Management, 18(S1), S89-S101. https://doi.org/10.1002/hpm.720

Marinakou, E., Giousmpasoglou, C., \& Paliktzoglou, V., 2016, The Brain Drain Phenomenon in Higher Education in Greece: Attitudes and Opinions on the Decision to Immigrate. Rd Annual International Conference on Humanities \& Arts in a Global World.

Marinakou, Evangelia, Giousmpasoglou, C., \& Paliktzoglou, V., 2016, The brain drain phenomenon in higher education in Greece: attitudes and opinions on the decision to immigrate. 3rd Annual International Conference on Humanities \& Arts in a Global World.

DOI: $10.25103 /$ ijbesar.132.07 
Markantonatou, M., 2013, Diagnosis, treatment, and effects of the crisis in Greece: A 'special case' or a 'test case'? (MPIfG Discussion paper, No 13/3).

Michail, D., \& Christou, A., 2018, Youth mobilities, crisis, and agency in Greece: Second-generation lives in liminal spaces and austere times. Transnational Social Review, 8(3), 245-257. https://doi.org/10.1080/21931674.2018.1511032

Mitsakis, F., \& Mendonca, P., 2017, "Brain-Drain" in an era of business and socio-economic uncertainty: the role of diversity training in managing social integration at the workplace. The case of Greece and Portugal. In EDI 2017 (Issue Working Paper).

Nemoto, T., \& Beglar, D., 2014, Developing Likert-Scale Questionnaires. In N. Sonda \& A. Krause (Eds.), JALT2013 Conference

Proceedings.

OECD, 2019, OECD Health Statistics 2019. http://www.oecd.org/health/health-data.htm

Panagiotakopoulos, A., 2020, "Investigating the factors affecting brain drain in Greece: looking beyond the obvious." World Journal of Entrepreneurship, Management and Sustainable Development, (ahead-of-print). https://doi.org/10.1108/wjemsd-102019-0076

Ricketts, T. C., 2010, The Migration of Surgeons. Annals of Surgery, $251(2)$, 363-367. https://doi.org/10.1097/SLA.obo13e3181c9b55a

Sheikh, A., Naqvi, S. H. A., Sheikh, K., Naqvi, S. H. S., \& Bandukda, M. Y., 2012, Physician migration at its roots: A study on the factors contributing towards a career choice abroad among students at a medical school in Pakistan. Globalization and Health, 8, 43. https://doi.org/10.1186/1744-8603-8-43

Sidiropoulos, I., Paschos, K., Platis, C. G., \& Kostagiolas, P. A., 2017, Medical Brain Drain in Debt-Stricken Greece: Is There a Way to Address It? Strategic Innovative Marketing, 373-379. https://doi.org/10.1007/978-3-319-33865-1_47

Special Eurobarometer 337, 2010, Geographical and labour market mobility Report. https://ec.europa.eu/commfrontoffice/publicopinion/archives/ebs/ebs_337_en.pdf

Syed, N. A., Khimani, F., Andrades, M., Ali, S. K., \& Paul, R., 2007, Reasons for migration among medical students from Karachi. Medical Education, 42(1), 61-68. https://doi.org/10.1111/j.1365-2923.2007.02904.x

Theodoropoulos, D., Kyridis, A., Zagkos, C., \& Konstantinidou, Z., 2014, Brain Drain Phenomenon in Greece: Young Greek scientists on their Way to Immigration, in an era of "crisis". Attitudes, Opinions and Beliefs towards the Prospect of Migration. Journal of Education and Human Development, 3(4), 229-248.

Theodossiou, G., Rigas, I., Thanou, E., \& Goulas, A., 2017, Financial crisis and brain drain: an investigation of the emigration intentions of Greek scientists. In N. Sykianakis, P. Polychronidou, \& A. Karasavvolgou Stogiannidi (Eds.), Proceedings of the 9th International Conference on the Economies of the Balkan and Eastern European Countries in the Changing World (EBEEC) (pp. 1-13). Springer.

Tsekeris, C., Pinguli, M., \& Georga, E., 2015, Young People’s Perception of Economic Crisis in Contemporary Greece: A Social Psychological Pilot Study (Research Paper No. 19).

Vandenbrande, T., Coppin, L., \& van der Hallen, P., 2006, Mobility in Europe Analysis of the 2005 Eurobarometer survey on geographical and labour market mobility.

This is an Open Access article distributed under the terms of the Creative Commons Attribution Licence 